BHUMI: Jurnal Agraria dan Pertanahan

Received: August 13, 2021; Reviewed: November 3, 2021; Accepted: November 30, 2021.

To cite this article: Nabila F, Shohibuddin M, \& Soetarto E. (2021). Perubahan Peran Perempuan Setelah Pengadaan Tanah untuk Pembangunan Yogyakarta International Airport: Kasus Kalurahan Kebonrejo di Kabupaten Kulonprogo, Daerah Istimewa Yogyakarta, Bhumi, Jurnal Agraria dan Pertanahan, 7 (2), 226-245.

DOI: 10.31292/bhumi.v7i2.494

Copyright: @2021 Fairuz Nabila, Mohamad Shohibuddin, Endriatmo Soetarto. All articles published in Jurnal Bhumi are licensed under a Creative Commons Attribution-ShareAlike 4.o International license.

Research Article

\title{
PERUBAHAN PERAN PEREMPUAN SETELAH PENGADAAN TANAH UNTUK PEMBANGUNAN YOGYAKARTA INTERNATIONAL AIRPORT: KASUS KALURAHAN KEBONREJO DI KABUPATEN KULONPROGO, DAERAH ISTIMEWA YOGYAKARTA
}

\author{
Fairuz Nabila $^{1 *}$, Mohamad Shohibuddin ${ }^{2}$, Endriatmo Soetarto ${ }^{3}$ \\ 1,2,3 Departemen Sains Komunikasi dan Pengembangan Masyarakat, Fakultas Ekologi Manusia \\ (FEMA), IPB University, Darmaga Bogor 1668o, Indonesia \\ *Koresponden E-mail: fairuz.nabila2105@gmail.com
}

\begin{abstract}
Women are one of the parties being affected by the process of land acquisition for the construction of public infrastructure. This article aims to analyse the change of women role after the implementation of land acquisition for the construction of Yogyakarta International Airport in Kulonprogo regency, Special Region of Yogyakarta. The research is carried out in Kebonrejo village, Temon district using quantitative approach supported by qualitative approach. Quantitative data are collected through a survey among 30 female respondents in the households selected by a simple random sampling and analysed through Rank Spearman test, while qualitative data are obtainded through documents review, participant observation and depth interview with key informants. The research findings demonstrate that there is a weak relationship between the participation of women throughout the implementation of land acquisition and the change of women role after the completion of land acquisition. This is due to the fact that despite there is a strong emphasize of public consultation and participation in the regulation of land acquisition, the will and power of the government is very strong and could not be influenced by the whole affected community. In addition, the process of land acquisition itself often put aside women's specific aspiration and intereset. Consequently, a relative equal gender relation within the household during land acquisition process didn't have any effect throughout the process and afterward.
\end{abstract}

Keywords: women participation, the role of women, land acquisition, development of public infrastructure.

Intisari:Perempuanadalah salah satu pihakyang terimbasoleh pengadaan tanahuntukpembangunan infrastruktur publik. Artikel ini bermaksud untuk menganalisis perubahan peran perempuan setelah pengadaan tanah untuk pembangunan Yogyakarta International Airport di Kabupaten Kulonprogo, Daerah Istimewa Yogyakarta. Penelitian lapangan dilakukan di Kalurahan Kebonrejo, Kapanewon Temon dengan menggunakan pendekatan kuantitatif yang didukung pendekatan kualitatif. Data kuantitatif diperoleh dari survei atas 30 responden perempuan dalam rumah tangga yang dipilih secara simple random sampling dan diolah dengan uji Rank Spearman, sementara data kualitatif diperoleh melalui studi dokumen, pengamatan terlibat dan wawancara mendalam dengan para informan. Hasil penelitian menunjukkan bahwa terdapat hubungan yang lemah antara keterlibatan perempuan selama proses pengadaan tanah untuk pembangunan Yogyakarta International Airport dengan peran perempuan setelah pengadaan tanah. Sekalipun keharusan konsultasi dan partisipasi publik sangat ditekankan dalam regulasi pengadaan tanah, namun kehendak dan kekuasaan yang kuat dari pemerintah membuat proses pengadaan tanah tidak dapat dipengaruhi oleh masyarakat terdampak secara keseluruhan. Selain itu, proses pengadaan tanah itu 
sendiri abai terhadap aspirasi dan kepentingan spesifik kaum perempuan. Akibatnya, relasi gender yang relatif setara di level rumah tangga selama proses pengadaan tanah tidak memiliki hubungan apa pun sepanjang proses tersebut maupun setelahnya.

Kata Kunci: keterlibatan perempuan, peran perempuan, pengadaan tanah, pembangunan infrastruktur publik.

\section{A. Pendahuluan}

Tanah sebagai salah satu sumber daya kegiatan pembangunan semakin hari semakin terbatas ketersediaannya. Untuk memperoleh tanah guna memenuhi kebutuhan masyarakat maupun kegiatan pembangunan, upaya transaksi dan pengadaan tanah (land deals and acquisition) tidak terelakkan dan makin marak dilakukan. Dalam kenyataannya, posisi pemilik tanah dengan pihak-pihak yang membutuhkan tanah sering kali tidak setara. Akibatnya, upaya perolehan tanah tidak jarang diwarnai aksi pemaksaan oleh pihak terakhir, baik secara halus atau terang-terangan. Hal ini pada akhirnya menyebabkan konflik struktural yang sering kali disertai dengan kekerasan.

Salah satu faktor yang memicu pengadaan tanah dalam skala luas adalah pembangunan infrastruktur untuk kepentingan umum, termasuk infrastruktur transportasi seperti bandara. Dewasa ini pembangunan bandara baru semakin dituntut seiring meningkatnya jumlah penumpang moda transportasi udara. Menurut Az-Zahra (2019), pembangunan bandara dapat menimbulkan dampak positif yang luas, seperti dari aspek pendidikan, pekerjaan, pendapatan, serta kepemilikan atau kekayaan. Pembangunan bandara juga berdampak besar pada pertumbuhan ekonomi (Andriyani 2011). Namun di pihak lain, pembangunan bandara yang membutuhkan tanah luas ini telah menyebabkan banyak warga kehilangan rumah, pekarangan, lahan pertanian, dan bahkan mata pencaharian.

Untuk menjamin pembangunan infrastruktur berjalan lancar dan hak-hak pemilik tanah tetap terlindungi, terdapat regulasi tentang pengadaan tanah dan pemberian ganti rugi kepada masyarakat terdampak, yaitu Undang-Undang No. 2 Tahun 2012 tentang Pengadaan Tanah bagi Pembangunan untuk Kepentingan Umum. Menurut Undang-Undang ini, pengadaan tanah untuk kepentingan umum harus diselenggarakan melalui beberapa tahapan, yaitu perencanaan, persiapan, pelaksanaan, dan penyerahan hasil. Adapun pihak yang berhak atas ganti rugi pengadaan tanah adalah pihak yang menguasai atau memiliki objek pengadaan tanah. Objek pengadaan tanah ini terdiri dari tanah, ruang atas tanah dan bawah tanah, bangunan, tanaman, benda yang berkaitan dengan tanah atau lainnya yang dapat dinilai.

Meskipun sudah ada regulasi ini, namun pengadaan tanah dalam skala luas tetap berpotensi dapat menimbulkan efek yang merugikan rakyat, khususnya kelompok miskin. Pengadaan tanah secara luas juga dapat memicu degradasi lingkungan, ancaman kedaulatan pangan, serta menimbulkan dampak psikologis dan sosial bagi korbannya. Salah satu pihak yang dapat merasakan kerugian paling berat akibat pengadaan tanah berskala luas ini adalah kaum perempuan. Pelaksanaan pengadaan tanah sering kali mengabaikan hak, kebutuhan dan kepentingan khusus perempuan sehingga cenderung memperburuk kondisi ketidaksetaraan gender yang ada di tengah masyarakat (Behrman et al. 2012).

Bahkan pada masyarakat di mana posisi perempuan cukup tinggi, pengadaan tanah skala besar juga dapat merubah pola relasi gender yang lebih setara. Hal ini diperlihatkan oleh penelitian Julia dan White (2012) pada komunitas di mana perempuan memiliki hak waris tanah dan akses atas tanah adat yang setara dengan laki-laki. Perempuan juga berperan besar dalam kegiatan pertanian dan pengambilan keputusan terkait tanah, kendati mereka tidak terlibat dalam struktur kepemimpinan. Namun, ketika terjadi pembangunan kebun kelapa sawit, proses pengadaan tanah yang dilakukan oleh pihak perusahaan justru tidak melibatkan perempuan. Selain itu, laki-laki sebagai kepala keluarga juga dianggap bertindak menjadi pemilik tanah, sedangkan perempuan hanya dapat dianggap sebagai pemilik tanah apabila bercerai atau suaminya meninggal. 
Kebonrejo, namun rencana ini urung karena aparat pemerintah setempat keberatan daerahnya dijadikan lokasi penelitian.

Pendekatan yang digunakan dalam penelitian adalah pendekatan kuantitatif dengan didukung pendekatan kualitatif. Pendekatan kuantitatif menggunakan metode survei, sementara pendekatan kualitatif dilakukan dengan studi dokumen, observasi lapangan serta wawancara mendalam dengan informan berdasarkan panduan pertanyaan. Data kualitatif yang diperoleh dimanfaatkan untuk memperdalam data kuantitatif sekaligus mempermudah memahami data dan informasi yang didapatkan di lapangan.

Responden pada penelitian ini adalah individu perempuan anggota rumah tangga di Kalurahan Kebonrejo yang terdampak proyek pengadaan tanah untuk pembangunan bandara. Jumlah sampel responden adalah 30 individu perempuan anggota rumah tangga. Pemilihan responden dilakukan dengan teknik simple random sampling agar dapat memberikan gambaran yang memadai atas populasi. Pemilihan informan dilakukan secara purposive, yaitu warga yang terdampak pengadaan tanah, tokoh masyarakat, lurah Kalurahan Kebonrejo, staf Kantor Pertanahan Kabupaten Kulonprogo, staf Kanwil Badan Pertanahan Nasional Yogyakarta, anggota Tim Appraisal, dan pihak lain yang relevan.

Data kuantitatif yang diperoleh dari metode survei kemudian diolah dengan menggunakan WPS Office 2019 dan Statistical Package for Social Science (SPSS) versi 26. Data tersebut dianalisis dengan menggunakan tabel frekuensi dan tabulasi silang menggunakan SPSS. Data kuantitatif ini selanjutnya diolah dengan uji Rank Spearman untuk mengetahui ada-tidaknya hubungan antara dua variabel (variabel independen dan variabel dependen), yaitu keterlibatan perempuan selama pelaksanaan pengadaan tanah terhadap perubahan peran perempuan setelah pengadaan tanah. Adapun data kualitatif dianalisis melalui tiga tahap, yaitu reduksi data, penyajian data, dan verifikasi.

\section{Hasil dan Pembahasan}

\section{Peran Perempuan Sebelum Pengadaan Tanah}

Secara tradisional, peran perempuan dalam kehidupan sehari-hari adalah melakukan kegiatan rumah tangga seperti memasak, mencuci, hingga mengurus anak. Namun, tidak semua perempuan di Kalurahan Kebonrejo hanya terlibat dalam kegiatan domestik, bahkan banyak yang harus bekerja untuk mencukupi kebutuhan rumah tangganya terutama mereka yang suaminya telah meninggal dunia. Selain menjadi pencari nafkah tunggal, terdapat pula perempuan yang turut bekerja membantu suami untuk mencukupi kebutuhan rumah tangganya.

\subsection{Penguasaan Tanah oleh Perempuan Sebelum Pengadaan Tanah}

Sebelum pembangunan bandara Yogyakarta International Airport, Kalurahan Kebonrejo merupakan daerah yang ditandai oleh pemukiman, hamparan sawah, dan perkebunan milik masyarakat. Terkait kepemilikan tanah, keberadaan adat sepikul sagendhongan menyebabkan hanya beberapa perempuan yang memiliki tanah sebelum adanya pengadaan tanah untuk pembangunan bandara.

"Kalau di sini itu memang jarang perempuan yang punya tanah. Paling pun kalau ada ya beberapa yang suaminya udah meninggal harta suaminya jadi milik dia. Karena sebenernya orang tua biasanya lebih percaya ke anak laki-laki untuk ngurus sawahnya." (TYM, 73 tahun)

Pada tabel 1 disajikan karakteristik rumah tangga responden berdasarkan tingkat penguasaan tanah dan pihak yang menguasainya. 
Tabel 1 Karakteristik Rumah Tangga Responden Menurut Luas Penguasaan Tanah dan Pihak yang Menguasai Sebelum Pengadaan Tanah

\begin{tabular}{|c|c|c|c|c|c|c|c|c|c|}
\hline \multirow{3}{*}{ Luas Penguasaan } & \multicolumn{9}{|c|}{ Penguasaan Tanah Oleh } \\
\hline & \multicolumn{3}{|c|}{ Laki-laki Saja } & \multicolumn{3}{|c|}{ Perempuan Saja } & \multicolumn{3}{|c|}{$\begin{array}{c}\text { Bersama-sama } \\
\text { (Harta Gono-Gini) }\end{array}$} \\
\hline & Jumlah RT & $\%$ & Luas $(\mathrm{Ha})$ & Jumlah RT & $\%$ & Luas (Ha) & Jumlah RT & $\%$ & Luas (Ha) \\
\hline Gurem & 21 & 78 & 3,672 & 5 & 71 & 0,3088 & 8 & 100 & 0,9133 \\
\hline Kecil & 4 & 15 & 2,9892 & 1 & 14 & 1,3803 & o & o & o \\
\hline Menengah & 1 & 4 & 2,4898 & 1 & 14 & 2,0525 & o & o & o \\
\hline Kaya & 1 & 4 & 3,775 & o & o & o & $\mathrm{o}$ & $\mathrm{o}$ & o \\
\hline Total & 27 & 100 & 12,926 & 7 & 100 & 3,7416 & 8 & 100 & 0,9133 \\
\hline
\end{tabular}

Keterangan: Gurem $=<0,5$ ha ; Kecil = 0,5-1,99 ha; Menengah $=2-2,99$ ha; Kaya $=\geq 3$ ha Sumber: Data primer, 2020

Berdasarkan tabel 1, terlihat bahwa sebagian besar tanah (total 12,926 ha) dikuasai oleh laki-laki saja, hanya 3,7416 ha dikuasai oleh perempuan, dan lebih sedikit lagi (o,9133 ha) yang dikuasai secara bersama-sama.

\subsection{Peran Ekonomi Perempuan Sebelum Pengadaan Tanah}

Peran perempuan sebelum pengadaan tanah dinilai dari tiga indikator, yaitu curahan waktu pada kegiatan pertanian, partisipasi dalam pengambilan keputusan rumah tangga khususnya pada tanah pertanian yang diusahakan, dan partisipasi dalam bekerja untuk mencukupi kebutuhan hidup seharihari. Peran ekonomi perempuan berdasarkan tiga indikator ini dapat dilihat pada Tabel 2.

Tabel 2 Karakteristik Responden Sebelum Pengadaan Tanah Berdasarkan Curahan Waktu pada Kegiatan Pertanian, Pengambilan Keputusan Rumah Tangga dan Pekerjaan Produktif

\begin{tabular}{lllllll}
\hline \multirow{2}{*}{$\begin{array}{c}\text { Tingkat Keterlibatan } \\
\text { Perempuan }\end{array}$} & \multicolumn{2}{c}{$\begin{array}{c}\text { Curahan Waktu pada } \\
\text { Kegiatan Pertanian }\end{array}$} & $\begin{array}{c}\text { Pengambilan Keputusan } \\
\text { Rumah Tangga }\end{array}$ & \multicolumn{2}{c}{$\begin{array}{c}\text { Pekerjaan } \\
\text { Produktif }\end{array}$} \\
\cline { 2 - 7 } & Jumlah & \% & Jumlah & \% & Jumlah & \% \\
\hline Rendah & 19 & 63,3 & 20 & 66,7 & 8 & 26,7 \\
Sedang & 9 & 30 & 6 & 20 & 19 & 63,3 \\
Tinggi & 2 & 6,7 & 4 & 13,3 & 3 & 10 \\
\hline Total & 30 & 100 & 30 & 100 & 30 & 100 \\
\hline
\end{tabular}

Sumber: Data primer, 2020

Tabel 2 menunjukkan bahwa berdasarkan curahan waktu pada kegiatan pertanian, peran perempuan berada pada tingkat yang rendah. Hal ini berarti laki-laki sebagai kepala keluarga berperan besar pada kegiatan pertanian di sawah, sedangkan perempuan hanya membantu pada kegiatan tertentu seperti mencabuti atau membersihkan rumput, membantu menanam dan memanen padi. Perempuan ditempatkan pada pekerjaan yang mudah di sawah karena mereka juga harus berperan menjadi ibu rumah tangga yang mengurus rumah dan anak.

"Yang lebih sering di sawah Bapak, tapi saya juga membantu misalnya nyiangin rumput, nanem sama manen. Itu pun biasanya dikerjakan bersama Bapak, bukan saya sendiri, karena saya kan juga harus bersih-bersih rumah terus ngurus anak." (SUN, 52 tahun)

Tabel 2 di atas juga menunjukkan bahwa partisipasi mayoritas responden dalam pengambilan keputusan rumah tangga sebelum pengadaan tanah berada di tingkat rendah. Hal ini karena mereka cenderung untuk mempercayakan pengambilan keputusan rumah tangga kepada laki-laki. 
"Yang mutusin ini-itu di sawah, semuanya Bapak. Tapi kalau kerja di sawah seperti nanem sama mupuk biasanya saya bantu. Kalau ada penghasilan semua yang megang uangnya saya, tapi untuk mutusin beli ini-itu biasanya didiskusikan bareng sama Bapak." (SUK, 55 tahun)

Akhirnya, Tabel 2 di atas juga menunjukkan bahwa partisipasi perempuan dalam pekerjaan produktif di luar rumah tangga sebelum pengadaan tanah berada di tingkat sedang, yaitu sebesar 19 orang atau 63,3 persen. Alasan mereka bekerja adalah menambah pendapatan harian demi mencukupi kebutuhan sehari-hari rumah tangga.

"Saya harus kerja Mbak, kalau engga mau makan apa, walaupun dapetnya seadanya." (KSH, 6o tahun)

Berdasarkan tiga indikator di atas, maka secara kumulatif peran perempuan di rumah tangga dalam kegiatan ekonomi sebelum pengadaan tanah dapat dilihat pada Tabel 3.

Tabel 3 Peran Perempuan dalam Kegiatan Ekonomi Sebelum Pengadaan Tanah

\begin{tabular}{lll}
\hline Peran Perempuan dalam Kegiatan Ekonomi & Jumlah (n) & Persentase (\%) \\
\hline Rendah & 17 & 56,7 \\
Sedang & 6 & 20 \\
Tinggi & 7 & 23,3 \\
\hline Total & 30 & 100 \\
\hline
\end{tabular}

Sumber: Data primer, 2020

Dari Tabel 3 terlihat bahwa peran ekonomi perempuan sebelum pengadaan tanah berada di tingkat rendah, yaitu sebanyak 17 responden atau 56,7 persen.

\subsection{Peran Sosial Perempuan Sebelum Pengadaan Tanah}

Sebelum pengadaan tanah, peran perempuan di Kalurahan Kebonrejo dalam kegiatan sosial dilakukan dalam bentuk pengajian, gotong royong, PKK, kelompok tani, arisan, forum kalurahan, dan lain-lain. Secara kumulatif, peran sosial responden sebelum pengadaan tanah dapat dilihat pada Tabel 4 .

Tabel 4 Peran Perempuan dalam Kegiatan Sosial Sebelum Pengadaan Tanah

\begin{tabular}{lll}
\hline \multicolumn{1}{c}{ Peran Perempuan dalam Kegiatan Sosial } & Jumlah (n) & Persentase (\%) \\
\hline Rendah & 2 & 6,7 \\
Sedang & 24 & 80 \\
Tinggi & 4 & 13,3 \\
\hline Total & 30 & 100 \\
\hline
\end{tabular}

Sumber: Data primer, 2020

Berdasarkan tabel ini terlihat bahwa peran perempuan dalam kegiatan sosial sebelum pengadaan tanah termasuk dalam tingkatan sedang, yakni sebanyak 24 responden atau 80\%. Hal ini menunjukkan bahwa perempuan cukup berperan aktif dalam berbagai kegiatan sosial di kalurahan.

"Dulu ibu-ibu aktif dalam kegiatan sosial seperti pengajian, Ibu PKK, gotong royong." (PYM, 69 tahun)

\section{Keterlibatan Perempuan Sepanjang Proses Pengadaan Tanah}

Proses pengadaan tanah di Kalurahan Kebonrejo berlangsung selama kurang lebih lima tahun sejak 2013 hingga 2018. Sepanjang proses pengadaan tanah ini, keterlibatan perempuan akan dilihat pada tiga 
tahap, yaitu pada saat pelaksanaan pengadaan tanah, pada saat proses negosiasi, dan pada saat proses penerimaan kompensasi.

\subsection{Keterlibatan Perempuan dalam Pelaksanaan Pengadaan Tanah}

Keterlibatan perempuan selama pelaksanaan pengadaan tanah meliputi tahap-tahap sebagai berikut: pemberitahuan, pendataan awal, konsultasi publik satu, konsultasi publik dua, konsultasi publik ulang kepada pihak yang berhak, pengumuman peta bidang tanah dan daftar nominasi pihak yang berhak, serta inventarisasi penguasaan, pemilikan, penggunaan, dan pemanfaatan tanah. Sepanjang proses ini, keterlibatan perempuan dilihat pada tiga arena berbeda, yaitu rumah tangga, komunitas dusun dan forum resmi kalurahan. Gambaran keterlibatan perempuan dalam pelaksanaan pengadaan tanah di tiga arena ini dapat dilihat pada Tabel 5 .

Tabel 5 Tingkat Keterlibatan Responden dalam Pelaksanaan Pengadaan Tanah di Kalurahan Kebonrejo Berdasarkan Arena Keterlibatannya, 2020

\begin{tabular}{|c|c|c|c|c|c|c|}
\hline \multirow{3}{*}{$\begin{array}{l}\text { Tingkat Keterlibatan Perempuan } \\
\text { dalam Pelaksanaan Pengadaan Tanah }\end{array}$} & \multicolumn{6}{|c|}{ Arena Keterlibatan } \\
\hline & \multicolumn{2}{|c|}{ Rumah Tangga } & \multicolumn{2}{|c|}{ Komunitas Dusun/Dukuh } & \multicolumn{2}{|c|}{ Forum Kalurahan } \\
\hline & Jumlah & $\%$ & Jumlah & $\%$ & Jumlah & $\%$ \\
\hline Rendah & 5 & 16,7 & 15 & 50 & 18 & 60 \\
\hline Sedang & o & o & 13 & 43,3 & 10 & 33,3 \\
\hline Tinggi & 25 & 83,3 & 2 & 6,7 & 2 & 6,7 \\
\hline Total (N) & 30 & 100 & 30 & 100 & 30 & 100 \\
\hline
\end{tabular}

Sumber: Data primer, 2020

Tabel 5 menunjukkan mayoritas tingkat keterlibatan perempuan pada arena rumah tangga berada di tingkat tinggi (83,3\%), sementara keterlibatan perempuan pada arena komunitas dusun maupun forum kelurahan sama-sama didominasi oleh tingkat yang rendah, yaitu berturut-turut sebesar 50\% dan 6o\%.

Keterlibatan perempuan pada arena rumah tangga berada di tingkat tinggi karena sejauh menyangkut pelepasan tanah perempuan ternyata dilibatkan di dalam pengambilan keputusan rumah tangga. Hal ini dapat dimengerti karena tanah merupakan aset yang sangat penting bagi ketahanan ekonomi rumah tangga sehingga pasangan suami istri memutuskannya secara bersama-sama.

"Diskusi sekeluarga terkait pelaksanaan pengadaan tanah. Mulai dari pemberitahuan awal sampai dengan pengumuman pihak yang berhak atas tanah pasti didiskusikan di rumah." (SUI, 47 tahun)

Namun pada arena komunitas dusun, keterlibatan perempuan ternyata didominasi oleh tingkat rendah. Hal ini karena yang hadir pada forum-forum di level dusun ini pada umumnya adalah laki-laki yang berperan sebagai kepala keluarga, meskipun tidak berarti bahwa perempuan dilarang hadir dan pada kenyataannya ada juga perempuan yang hadir di forum dusun tersebut.

"Istri nggak ikut kalau ada forum di pedukuhan atau forum kalurahan karena undangannya hanya satu untuk kepala keluarga. Kalau forum dukuh masih boleh ajak istri, tapi yang wajibnya memang hanya kepala keluarga saja." (SMO, 41 tahun)

Pada forum resmi di kalurahan, keterlibatan perempuan makin sedikit lagi dengan lebih dari separuh responden $(60 \%)$ berada di tingkat rendah. Hal ini dikarenakan setiap rumah tangga terdampak hanya memperoleh satu undangan untuk salah satu anggotanya. Undangan ini sebenarnya untuk pemilik tanah di rumah tangga tersebut, baik laki-laki atau perempuan, namun pada umumnya yang selalu hadir adalah kepala keluarga dalam hal ini laki-laki. 
"Ibu ikut saja keputusan dari saya, karena kan undangan cuma satu untuk kepala keluarga. Kalau perempuan yang ikut biasanya itu janda. Tapi ada juga yang istrinya ikut, tapi kalau saya pikir buat apa. Wong nggak punya tanah kok ikut-ikutan." (SDT, 62 tahun)

Apabila keterlibatan perempuan pada ketiga arena di atas diakumulasikan, maka dapat diketahui bahwa tingkat keterlibatan mereka dalam pelaksanaan pengadaan tanah didominasi oleh tingkat sedang seperti tercantum pada Tabel 6 .

Tabel 6 Tingkat Keterlibatan Responden dalam Pelaksanaan Pengadaan Tanah di Kalurahan Kebonrejo, 2020

\begin{tabular}{llll}
\hline \multicolumn{1}{c}{ Tingkat Keterlibatan Perempuan } & & Jumlah (n) & Persentase (\%) \\
\hline Rendah & 8 & 26,7 \\
Sedang & 17 & 56,7 \\
Tinggi & 5 & 16,7 \\
\hline Total (N) & 30 & 100 \\
\hline
\end{tabular}

Sumber: Data primer, 2020

Dari Tabel 6 terlihat bahwa secara keseluruhan keterlibatan perempuan dalam pelaksanaan pengadaan tanah berada di tingkat sedang.

\subsection{Keterlibatan Perempuan dalam Proses Negosiasi}

Tahapan negosiasi dalam pengadaan tanah dilakukan mulai dari penilaian ganti rugi hingga musyawarah besaran kompensasi. Keterlibatan perempuan menyangkut tahap ini juga dilihat pada arena rumah tangga, komunitas dusun, dan forum resmi kalurahan. Gambaran keterlibatan perempuan di tiga arena ini dapat dilihat pada Tabel 7 .

Tabel 7 Tingkat Keterlibatan Responden dalam Proses Negosiasi di Kalurahan Kebonrejo Berdasarkan Arena Keterlibatannya, 2020

\begin{tabular}{llccccc}
\hline \multirow{2}{*}{$\begin{array}{c}\text { Tingkat Keterlibatan Perempuan } \\
\text { dalam Proses Negosiasi }\end{array}$} & \multicolumn{5}{c}{ Arena Keterlibatan } \\
\cline { 2 - 7 } & \multicolumn{2}{c}{ Rumah Tangga } & \multicolumn{2}{c}{$\begin{array}{c}\text { Komunitas } \\
\text { Dusun/Dukuh }\end{array}$} & Forum Kalurahan \\
\cline { 2 - 7 } & Jumlah & $\%$ & Jumlah & $\%$ & Jumlah & $\%$ \\
\hline Rendah & 5 & 16,7 & 15 & 50 & 16 & 53,3 \\
Sedang & 5 & 16,7 & 11 & 36,7 & 11 & 36,7 \\
Tinggi & 20 & 66,7 & 4 & 13,3 & 3 & 10 \\
\hline Total $(\mathrm{N})$ & 30 & 100 & 30 & 100 & 30 & 100 \\
\hline
\end{tabular}

Sumber: Data primer, 2020

Tabel 7 menunjukkan bahwa pada tahap negosiasi keterlibatan perempuan yang tinggi terjadi pada arena rumah tangga $(66,7 \%)$, sementara keterlibatan mereka pada arena komunitas dusun maupun forum resmi kelurahan sama-sama didominasi oleh tingkat rendah, yaitu berturut-turut 5o\% dan 53,3\%. Pada level rumah tangga, suami-istri selalu berembug mengenai nilai tanah yang harus dilepaskan ke pemerintah, meskipun pada akhirnya keputusan terakhir tidak berada di tangan mereka.

"Terlebih dahulu diskusi sama istri di rumah kira-kira kalau dibeli oleh pemerintah dihargai berapa. Namun, akhirnya, semua keputusan terkait penilaian kompensasi berada di tangan tim appraisal sehingga tidak bisa protes." (IMI, 6o tahun)

Apabila keterlibatan perempuan pada ketiga arena di atas diakumulasikan, maka dapat diketahui bahwa tingkat keterlibatan mereka dalam proses negosiasi berada pada tingkat sedang, sebagaimana tercantum pada Tabel 8 . 
Tabel 8 Tingkat Keterlibatan Responden dalam Proses Negosiasi di Kalurahan Kebonrejo, 2020

\begin{tabular}{lll}
\hline \multicolumn{1}{c}{ Tingkat Keterlibatan Perempuan } & Jumlah (n) & Persentase (\%) \\
\hline Rendah & 7 & 23,3 \\
Sedang & 16 & 53,3 \\
Tinggi & 7 & 23,3 \\
\hline Total (N) & 30 & 100 \\
\hline
\end{tabular}

Sumber: Data primer, 2020

Dari Tabel 8 terlihat bahwa secara keseluruhan keterlibatan perempuan dalam proses negosiasi berada di tingkat sedang. Hal ini dimungkinkan berkat masih tingginya tingkat keterlibatan perempuan pada arena rumah tangga, meskipun pada arena komunitas dusun dan forum resmi di kelurahan tingkat keterlibatan mereka berada di tingkat rendah.

\subsection{Keterlibatan Perempuan dalam Proses Penerimaan Kompensasi}

Penerimaan kompensasi diberikan setelah terjadi pelepasan hak atas tanah oleh pemilik tanah yang ditandai dengan penyerahan bukti hak atas tanah dan penandatanganan dokumen. Apabila pemilik tanah tidak dapat hadir, dia dapat mewakilkan kepada pihak lain dengan disertai surat kuasa. Dalam penelitian ini, keterlibatan perempuan dalam proses penerimaan kompensasi berdasarkan pihak yang menandatangani dokumen dapat dilihat pada Tabel 9.

Tabel 9 Tingkat Keterlibatan Responden dalam Proses Penerimaan Kompensasi Berdasarkan Pihak yang Menandatangani Dokumen di Kalurahan Kebonrejo

\begin{tabular}{|c|c|c|c|c|c|c|c|c|}
\hline \multirow{3}{*}{ Pemilik Tanah } & \multicolumn{8}{|c|}{ Penanda Tangan Dokumen } \\
\hline & \multicolumn{2}{|l|}{ Laki-laki } & \multicolumn{2}{|c|}{ Perempuan } & \multirow{2}{*}{$\begin{array}{c}\text { Bersama } \\
\text { Jumlah } \\
\end{array}$} & \multicolumn{3}{|c|}{ Total } \\
\hline & Jumlah & $\%$ & Jumlah & $\%$ & & $\%$ & Jumlah & $\%$ \\
\hline Laki-Laki & 28 & 58,3 & 5 & 10,4 & 1 & 2,1 & 34 & 70,8 \\
\hline Perempuan & $\mathrm{O}$ & $\mathrm{O}$ & 3 & 6,3 & $\mathrm{O}$ & $\mathrm{O}$ & 3 & 6,3 \\
\hline Bersama & 5 & 10,4 & 2 & 4,2 & 4 & 8,3 & 11 & 22,9 \\
\hline Total & 34 & 70,8 & 9 & 18,8 & 5 & 10,4 & 48 & 100 \\
\hline
\end{tabular}

Sumber: Data primer, 2020

Dari Tabel 9 ini terlihat bahwa perempuan sangat rendah keterlibatannya sebagai penanda tangan dokumen apabila tanah yang diganti rugi adalah milik laki-laki atau milik bersama. Keterlibatan perempuan lebih tinggi apabila tanah yang diganti merupakan tanah miliknya sendiri.

"Yang nandatanganin terkait kompensasi uang bandara itu Bapak beserta ahli waris

keluarga Bapak lainnya. Saya nggak ikut-ikutan Mbak, karena tanah itu kan tanah warisan keluarga Bapak." (EDH, 39 tahun)

Penerimaan kompensasi dapat dilakukan oleh orang yang berbeda karena kompensasi diberikan dalam bentuk buku tabungan dengan rekening yang baru dibuka. Buku tabungan ini baru diberikan setelah semua urusan selesai, mulai penyerahan bukti kepemilikan tanah berupa sertipikat hingga penandatanganan dokumen. Tingkat keterlibatan perempuan dalam penerimaan kompensasi ini dapat dilihat pada Tabel 10. 
Tabel 10 Tingkat Keterlibatan Responden dalam Proses Penerimaan Kompensasi Berdasarkan Pihak Penerima Kompensasi di Kalurahan Kebonrejo

\begin{tabular}{|c|c|c|c|c|c|c|c|c|}
\hline \multirow{3}{*}{ Pemilik Tanah } & \multicolumn{8}{|c|}{ Penerima Kompensasi } \\
\hline & \multicolumn{2}{|l|}{ Laki-laki } & \multicolumn{2}{|c|}{ Perempuan } & \multirow{2}{*}{$\begin{array}{c}\text { Bersama } \\
\text { Jumlah }\end{array}$} & \multicolumn{3}{|c|}{ Total } \\
\hline & Jumlah & $\%$ & Jumlah & $\%$ & & $\%$ & Jumlah & $\%$ \\
\hline Laki-Laki & 25 & 52,1 & 4 & 8,3 & 5 & 10,4 & 34 & 70,8 \\
\hline Perempuan & o & o & 3 & 6,3 & o & o & 3 & 6,3 \\
\hline Bersama & 4 & 8,3 & 1 & 2,1 & 6 & 12,5 & 11 & 22,9 \\
\hline Total & 29 & 60,4 & 8 & 16,7 & 11 & 22,9 & 48 & 100 \\
\hline
\end{tabular}

Sumber: Data primer, 2020

Berdasarkan tabel ini terlihat bahwa dalam penerimaan kompensasi, pihak yang menjadi penerima didominasi oleh laki-laki. Meski demikian, jika tanah milik perempuan, maka perempuan pula yang menjadi penerima kompensasi. Demikian pula, terdapat empat perempuan yang menjadi penerima kompensasi meski tanah yang diganti rugi adalah milik laki-laki.

Dalam hal pengelolaan uang kompensasi yang didapatkan dari pengadaan tanah, tingkatan keterlibatan perempuan dapat dilihat pada Tabel 11.

Tabel 11 Tingkat Keterlibatan Responden dalam Proses Penerimaan Kompensasi Berdasarkan Pihak Pengelola Kompensasi di Kalurahan Kebonrejo

\begin{tabular}{|c|c|c|c|c|c|c|c|c|}
\hline \multirow{3}{*}{ Pemilik Tanah } & \multicolumn{8}{|c|}{ Pengelola Kompensasi } \\
\hline & \multirow{2}{*}{$\begin{array}{c}\text { Laki-laki } \\
\text { Jumlah } \\
\end{array}$} & \multicolumn{3}{|c|}{ Perempuan } & \multirow{2}{*}{$\begin{array}{c}\text { Bersama } \\
\text { Jumlah }\end{array}$} & \multicolumn{3}{|c|}{ Total } \\
\hline & & $\%$ & Jumlah & $\%$ & & $\%$ & Jumlah & $\%$ \\
\hline Laki-Laki & 16 & 33,3 & 8 & 16,7 & 10 & 20,8 & 34 & 70,8 \\
\hline Perempuan & o & o & 2 & 4,2 & 1 & 2,1 & 3 & 6,3 \\
\hline Bersama & 3 & 6,3 & 6 & 12,5 & 2 & 4,2 & 11 & 22,9 \\
\hline Total & 19 & 39,6 & 16 & 33,3 & 13 & 27,1 & 48 & 100 \\
\hline
\end{tabular}

Sumber: Data primer, 2020

Berdasarkan tabel 11, terlihat bahwa pengelolaan kompensasi didominasi oleh laki-laki sebagai pemilik tanah. Namun, keterlibatan perempuan dalam pengelolaan kompensasi jauh lebih besar dibandingkan penandatanganan dan penerimaan uang kompensasi karena beberapa rumah tangga memutuskan untuk mengelola uang kompensasi secara bersama-sama.

“Untuk penggunaan atau pengelolaan uang kompensasi akan digunakan untuk apa diskusi sama istri terlebih dahulu. Namanya berkeluarga walaupun tanah atas nama saya segala sesuatu untuk ke depan tetap harus didiskusikan dengan istri." (PER, 7o tahun)

Berdasarkan keputusan yang telah ditetapkan pada tahap negosiasi, bentuk kompensasi yang diberikan kepada masyarakat adalah uang tunai. Bagi warga masyarakat yang kehilangan tanah dan rumah, mereka dapat membeli tanah dan membangun rumah di tempat relokasi di mana setiap keluarga mendapat jatah $200 \mathrm{~m}^{2}$ untuk didirikan rumah yang pembangunannya disesuaikan dengan selera dan kemampuan masing-masing.

“Tanah relokasi yang sekarang adalah tanah kas kalurahan yang semula menjadi sumber pendapatan asli kalurahan. Tanah ini digunakan untuk masyarakat yang kehilangan rumah, dengan cara tanah tersebut dibeli. Kalurahan diberi uang tunai karena tidak ada lagi tanah kosong untuk pengganti tanah masyarakat tersebut." (ENI, 28 tahun)

Berdasarkan uraian di atas, maka secara keseluruhan tingkat keterlibatan perempuan di sepanjang proses pengadaan tanah berada pada tingkat sedang seperti terlihat pada Tabel 12. 
Tabel 12 Tingkat Keterlibatan Responden Sepanjang Proses Pengadaan Tanah di Kalurahan Kebonrejo

\begin{tabular}{lll}
\hline Tingkat Keterlibatan Perempuan & Jumlah (n) & Persentase (\%) \\
\hline Rendah & 12 & 40 \\
Sedang & 14 & 46,7 \\
Tinggi & 4 & 13,3 \\
\hline Total (N) & 30 & 100 \\
\hline
\end{tabular}

Sumber: Data primer, 2020

Temuan ini berbeda dari hasil penelitian Nhantumbo dan Salomao (2010) bahwa sekalipun perempuan sangat terlibat di bidang pertanian, namun mereka tidak dilibatkan selama proses pengadaan tanah, baik pada tahap konsultasi, negosiasi, serta penandatanganan dokumen terkait kompensasi. Kondisi yang berbeda justru ditemukan oleh penelitian ini. Sekalipun sebelum pengadaan tanah peran perempuan relatif rendah, namun partisipasi perempuan relatif baik pada level rumah tangga di semua tahapan pengadaan tanah, sekalipun pada level kelompok masyarakat atau forum resmi kalurahan tingkat partisipasi mereka bervariasi dari tingkat sedang hingga tingkat rendah.

\section{Perubahan Peran Perempuan Setelah Pengadaan Tanah}

Seperti halnya peran perempuan sebelum pengadaan tanah, perubahan peran setelah pengadaan tanah juga dinilai berdasarkan tiga aspek, yakni tingkat penguasaan tanah, tingkat keterlibatan dalam kegiatan ekonomi, dan tingkat keterlibatan dalam kegiatan sosial.

\subsection{Penguasaan Perempuan atas Tanah Setelah Pengadaan Tanah}

Perbandingan perubahan penguasaan tanah oleh perempuan sebelum dan setelah pengadaan tanah dapat dilihat pada Tabel 13.

Tabel 13 Perubahan Penguasaan Tanah Sebelum dan Setelah Pengadaan Tanah Menurut Luas Penguasaan Tanah dan Pihak yang Menguasai

\begin{tabular}{|c|c|c|c|c|c|c|c|c|c|}
\hline \multirow{3}{*}{ Luas Penguasaan } & \multicolumn{9}{|c|}{ Penguasaan Tanah Oleh } \\
\hline & \multicolumn{3}{|c|}{ Laki-laki Saja } & \multicolumn{3}{|c|}{ Perempuan Saja } & \multicolumn{3}{|c|}{$\begin{array}{c}\text { Bersama-sama } \\
\text { (Harta Gono-Gini) }\end{array}$} \\
\hline & Jumlah RT & $\%$ & Luas (Ha) & Jumlah RT & $\%$ & Luas (Ha) & Jumlah RT & $\%$ & Luas (Ha) \\
\hline \multicolumn{10}{|c|}{ Sebelum Pengadaan Tanah } \\
\hline Gurem & 21 & 78 & 3,672 & 5 & 71 & 0,3088 & 8 & 100 & 0,9133 \\
\hline Kecil & 4 & 15 & 2,9892 & 1 & 14 & 1,3803 & o & o & o \\
\hline Menengah & 1 & 4 & 2,4898 & 1 & 14 & 2,0525 & o & o & o \\
\hline Kaya & 1 & 4 & 3,775 & $\mathrm{o}$ & o & o & o & $\mathrm{o}$ & o \\
\hline Total & 27 & 100 & 12,926 & 7 & 100 & 3,7416 & 8 & 100 & 0,9133 \\
\hline \multicolumn{10}{|c|}{ Setelah Pengadaan Tanah } \\
\hline Gurem & 15 & 68 & 2,4116 & 11 & 85 & 1,0972 & 2 & 100 & 0,2 \\
\hline Kecil & 3 & 14 & 2,2444 & 2 & 15 & 2,312 & o & o & o \\
\hline Menengah & 2 & 9 & 4,45 & o & o & o & o & o & o \\
\hline Kaya & 2 & 9 & 6,547 & $\mathrm{o}$ & $\mathrm{o}$ & $\mathrm{o}$ & o & $\mathrm{o}$ & o \\
\hline Total & 22 & 100 & 15,653 & 13 & 100 & 3,4092 & 2 & 100 & 0,2 \\
\hline
\end{tabular}

Keterangan: Gurem $=<0,5$ ha ; Kecil = 0,5-1,99 ha; Menengah $=2-2,99$ ha; Kaya $=\geq 3$ ha Sumber: Data primer, 2020

Dari Tabel 13 terlihat bahwa luas tanah yang dikuasai oleh perempuan secara keseluruhan berkurang dari 3,7416 ha sebelum pengadaan tanah menjadi 3,4092 ha setelah pengadaan tanah. Meski demikian, jumlah perempuan yang menguasai tanah bertambah dari tujuh orang menjadi 13 orang. Hal ini terjadi 
karena sebagian mampu membeli tanah baru dari uang kompensasi, sebagian lain karena menerima harta warisan peninggalan suaminya yang meninggal.

"Karena tanah milik almarhum suami saya, jadi langsung dibagi ke anak-anak. Jadi terserah mereka mau dipakai buat apa. Paling, bagian untuk saya sendiri cuma untuk pergi haji. Mau beli tanah lagi buat apa, saya sudah tua. Terus tanah sekarang di sini mahal, kalau di luar Kulonprogo lebih murah, cuma jauh nggak ada yang urus." (SRH, 65 tahun)

Di sisi lain, luas penguasaan tanah oleh laki-laki secara keseluruhan justru bertambah setelah pengadaan tanah ini, yaitu dari semula 12,926 ha menjadi 15,653 ha. Hal ini terjadi karena uang ganti rugi yang mereka terima digunakan untuk membeli tanah di tempat lain. Meski demikian, pertambahan luas penguasaan tanah ini hanya terjadi pada golongan petani menengah dan kaya, sementara luas penguasaan golongan petani gurem dan kecil semakin berkurang.

\subsection{Peran Ekonomi Perempuan Setelah Pengadaan Tanah}

Perbedaan peran ekonomi perempuan ekonomi terlihat pada perubahan pekerjaan utama perempuan sebelum dan setelah pelaksanaan pengadaan tanah seperti dapat dilihat pada Tabel 14.

Tabel 14 Perubahan Peran Ekonomi Perempuan Setelah Pengadaan Tanah

Berdasarkan Jenis Pekerjaan Utama

\begin{tabular}{lllll}
\hline \multirow{2}{*}{ Pekerjaan Utama Perempuan } & \multicolumn{2}{c}{ Sebelum } & \multicolumn{2}{c}{ Setelah } \\
\cline { 2 - 5 } Petani Pemilik Tanah & Jumlah & \multicolumn{2}{c}{ Jumlah } & \% \\
Petani Penggarap & 20 & 66,7 & 4 & 13,3 \\
Pedagang/Wiraswasta & 1 & 3,3 & 2 & 6,7 \\
Buruh Tani & 3 & 10 & 7 & 23,3 \\
Guru & 0 & 0 & 2 & 6,7 \\
Pegawai Negeri Sipil & 2 & 6,7 & 2 & 6,7 \\
Pegawai Pemerintah & 1 & 3,3 & 1 & 3,3 \\
Beternak & 1 & 3,3 & 1 & 3,3 \\
Berkebun & 0 & 0 & 2 & 6,7 \\
Ibu Rumah Tangga & 0 & 0 & 5 & 16,7 \\
\hline Total & 2 & 6,7 & 4 & 13,3 \\
\hline
\end{tabular}

Tabel 14 menunjukkan bahwa pekerjaan utama perempuan sebelum pengadaan tanah didominasi oleh perempuan yang bekerja sebagai sebagai petani pemilik tanah, dengan catatan tanah dimaksud termasuk yang dimiliki oleh suami. Namun, setelah adanya pengadaan tanah, pekerjaan perempuan didominasi oleh pedagang atau wiraswasta. Hal ini karena banyak masyarakat, termasuk perempuan, yang kehilangan tanah milik atau tanah garapan akibat pengadaan tanah. Tidak semua petani yang mendapatkan uang kompensasi mampu membeli tanah baru, terutama mereka yang tanahnya sempit sehingga uang kompensasi yang diterima tidak terlalu banyak. Dalam kondisi demikian, mereka terpaksa harus berganti profesi menyesuaikan dengan kondisi dan situasi setelah pengadaan tanah.

"Gimana mau beli tanah Mbak, bangun rumah aja uangnya pas-pasan. Jadi, ya sekarang ngeburuh tani. Kalau dulu ada tanah sendiri.” (TYM, 69 tahun)

"Beda Mbak, kalau dulu ada tanah sendiri. Kalau sekarang ya kadang-kadang ikut buruh ke sawah, kadang ya enggak. Tergantung ada yang mau pakai jasa buruh atau enggak." (JSH, 63 tahun) 
"Walaupun sawah udah kena bandara, tapi tetap harus bisa manfaatin pekarangan yang ada biar menghasilkan. Jadi, ya ditanemin kelengkeng, singkong, jeruk, kacang tanah, macem-macem pokoknya." (SBH, 60 tahun)

Pada Tabel 13 memang ditunjukkan bahwa jumlah perempuan yang memiliki tanah bertambah setelah pengadaan tanah karena sebagian di antara mereka mampu membeli tanah baru. Namun, tanah yang dibeli tidak lagi di tempat domisili karena harganya sudah mahal, melainkan di kecamatan atau bahkan kabupaten berbeda untuk digarap orang lain dengan sistem bagi hasil atau sewa.

“Orang tua kaya' saya ini udah bingung Mbak mau kerja apa, kalau dulu iya petani tapi kalau sekarang tanah di deket sini udah mahal. Makanya beli tanah ke Purworejo terus diburuhkan ke orang atau disewain." (PYM, 69 tahun)

"Kalau mau cari tanah di sini susah Mbak, harganya udah naik dua kali lipat. Jadi, saya sama suami mutusin beli tanah di kampung halaman suami dan diurus oleh keluarga suami. Nanti hasilnya dibagi dua. Kalau saya dagang aja di sini sama suami” (WEN, 42 tahun)

Hasil penelitian ini menunjukkan bahwa secara keseluruhan keterlibatan perempuan dalam kegiatan ekonomi semakin rendah setelah pengadaan tanah, seperti ditunjukkan dalam Tabel 15.

Tabel 15 Perubahan Peran Perempuan dalam Kegiatan Ekonomi Sebelum dan Setelah Pengadaan Tanah

\begin{tabular}{lllll}
\hline \multirow{2}{*}{ Peran Perempuan dalam Kegiatan Ekonomi } & \multicolumn{2}{c}{ Sebelum } & \multicolumn{2}{c}{ Setelah } \\
\cline { 2 - 6 } & Jumlah & \multicolumn{1}{c}{$\%$} & Jumlah & $\%$ \\
\hline Rendah & 17 & 56,7 & 21 & 70 \\
Sedang & 6 & 20 & 6 & 20 \\
Tinggi & 7 & 23,3 & 3 & 10 \\
\hline Total & 30 & 100 & 30 & 100 \\
\hline
\end{tabular}

Sumber: Data primer, 2020.

\subsection{Peran Sosial Perempuan Setelah Pengadaan Tanah}

Setelah adanya pengadaan tanah, terjadi perubahan sosial yang cukup besar di Kalurahan Kebonrejo. Semakin banyak pendatang yang masuk, sementara banyak warga asli yang harus direlokasi ke tempat baru meski tetap berada di kalurahan yang sama. Akibatnya, sistem integrasi sosial yang lama mengalami banyak goncangan.

Kondisi semacam ini turut memengaruhi keterlibatan perempuan dalam kegiatan sosial. Banyak perempuan mengakui mereka tidak terlalu aktif lagi dalam berbagai kegiatan sosial di lingkungan mereka yang telah berubah atau di lingkungan yang baru tempat mereka direlokasi. Perubahan peran sosial perempuan ini tergambar pada tabel 16.

Tabel 16 Perubahan Peran Perempuan dalam Kegiatan Sosial Sebelum dan Setelah Pengadaan Tanah

\begin{tabular}{lllll}
\hline \multirow{2}{*}{ Peran Perempuan dalam Kegiatan Sosial } & \multicolumn{3}{c}{ Sebelum } & \multicolumn{2}{c}{ Setelah } \\
\cline { 2 - 6 } & Jumlah & \% & Jumlah & $\%$ \\
\hline Rendah & 2 & 6,7 & 8 & 26,7 \\
Sedang & 24 & 80 & 19 & 63,3 \\
Tinggi & 4 & 13,3 & 3 & 10 \\
\hline Total & 2 & 6,7 & 30 & 100 \\
\hline
\end{tabular}

Sumber: Data primer, 2020 
Tabel 16 menunjukkan tingkat keterlibatan perempuan dalam kegiatan sosial semakin rendah setelah terjadi pengadaan tanah. Mereka yang dulu aktif mengikuti kegiatan sosial seperti pengajian, kelompok tani, PKK, arisan, gotong-royong, dan lainnya tidak bisa mengikuti kegiatan tersebut, misalnya karena tidak memiliki tanah pertanian lagi sehingga tidak dapat bergabung dengan kelompok tani dan harus berpindah ke tempat relokasi.

Perempuan yang pindah ke tempat relokasi juga harus menyesuaikan diri dengan lingkungan dan tetangga yang baru. Apalagi banyak masyarakat yang membeli rumah di tempat relokasi, namun memilih untuk mengontrakkan rumahnya kepada para pendatang.

"Mau ikut kegiatan seperti gotong-royong juga masyarakatnya banyak pendatang. Jadi ya paling kalau ikut kegiatan atas nama Rukun Warga di tempat yang lama, bukan di relokasi." (EDH, 39 tahun)

Secara keseluruhan, kondisi perubahan peran perempuan setelah pengadaan tanah ditinjau dari luas penguasaan tanah dan keterlibatan dalam aktivitas ekonomi dan sosial dapat dilihat pada Tabel 17.

Tabel 17 Kondisi Perubahan Peran Perempuan Setelah Pengadaan Tanah di Kalurahan Kebonrejo

\begin{tabular}{lll}
\hline Kondisi Perubahan Peran Perempuan & Jumlah (n) & Persentase (\%) \\
\hline Rendah & 21 & 70 \\
Sedang & 6 & 20 \\
Tinggi & 3 & 10 \\
\hline Total & 30 & 100 \\
\hline
\end{tabular}

Sumber: Data primer, 2020

Berdasarkan Tabel 17 terlihat bahwa kondisi peran perempuan setelah pengadaan tanah didominasi oleh kategori rendah; dalam arti, lebih buruk jika dibandingkan dengan kondisi sebelum pengadaan tanah. Pelemahan kondisi peran perempuan semacam ini sejalan dengan temuan Majunder (2014) di Desa Gokulpur bahwa pengadaan tanah skala luas untuk pembangunan infrastuktur telah menyebabkan peran perempuan semakin rendah karena mereka harus dihadapkan pada berbagai kesulitan ekonomi dan sosial.

\section{Hubungan Tingkat Keterlibatan Perempuan Selama Proses Pengadaan Tanah dengan Perubahan Peran Perempuan Setelah Pengadaan Tanah}

Bagian ini akan membahas hubungan antara tingkat keterlibatan perempuan sepanjang proses pengadaan tanah dengan perubahan peran perempuan setelah pengadaan tanah. Dengan menggunakan tabulasi silang, hubungan di antara dua variabel dapat dilihat pada Tabel 18.

Tabel 18 Hubungan Tingkat Keterlibatan Perempuan Selama Proses Pengadaan Tanah dengan Perubahan Peran Perempuan Setelah Pengadaan Tanah di Kalurahan Kebonrejo

\begin{tabular}{|c|c|c|c|c|c|c|c|c|}
\hline \multirow{3}{*}{$\begin{array}{l}\text { Tingkat Keterlibatan Perempuan } \\
\text { Selama Proses Pengadaan Tanah }\end{array}$} & \multicolumn{8}{|c|}{ Perubahan Peran Perempuan Setelah Pengadaan Tanah } \\
\hline & \multicolumn{2}{|c|}{ Rendah } & \multicolumn{2}{|c|}{ Sedang } & \multicolumn{2}{|c|}{ Tinggi } & \multicolumn{2}{|c|}{ Total } \\
\hline & $\mathbf{n}$ & $\%$ & $\mathbf{n}$ & $\%$ & $\mathbf{n}$ & $\%$ & $\mathbf{n}$ & $\%$ \\
\hline Rendah & 10 & 33,3 & o & o & 2 & 6,7 & 12 & 40 \\
\hline Sedang & 8 & 26,7 & 5 & 16,7 & 1 & 3,3 & 14 & 46,7 \\
\hline Tinggi & 3 & 10 & 1 & 3,3 & $\mathrm{o}$ & o & 4 & 13,3 \\
\hline Total & 21 & 70 & 6 & 20 & 3 & 10 & 30 & 100 \\
\hline
\end{tabular}

Sumber: Data primer, 2020

Berdasarkan Tabel 18, terlihat bahwa angka tingkat keterlibatan perempuan selama proses pengadaan tanah dengan perubahan peran perempuan setelah pengadaan tanah paling banyak berada pada kategori 
rendah. Untuk menguji hubungan di antara dua variabel tersebut dilakukan uji statistik Rank Spearman memakai SPSS versi 26 dengan menggunakan signfikansi two tailed dengan selang kepercayaan o,05 atau 95 persen.

Tabel 19 Hasil Uji Korelasi antara Tingkat Keterlibatan Perempuan Selama Proses Pengadaan Tanah dengan Perubahan Peran Perempuan Setelah Pengadan Tanah di Kalurahan Kebonrejo

\begin{tabular}{lll}
\hline & & \multicolumn{1}{c}{$\begin{array}{c}\text { Perubahan Peran Perempuan } \\
\text { Setelah Pengadaan Tanah }\end{array}$} \\
\hline Tingkat Keterlibatan Perempuan & Koefisien Korelasi & 0,117 \\
Selama Proses Pengadaan Tanah & Sig (2-tailed) & 0,538 \\
& $\mathrm{~N}$ & 30 \\
\hline
\end{tabular}

Sumber: Data primer, 2020

Hasil uji statistik Rank Spearman menunjukkan bahwa nilai Sig. (2-tailed) sebesar 0,538 atau lebih besar dari 0,05. Dari sini dapat disimpulkan bahwa variabel tingkat keterlibatan perempuan selama proses pengadaan tanah tidak memiliki hubungan yang signifikan dengan variabel peran perempuan setelah pengadaan tanah. Lalu, nilai Correlation Coefficient bernilai positif sebesar o,117 sehingga dapat disimpulkan bahwa arah hubungan dua variabel bersifat searah dan lemah.

Selanjutnya, analisis hubungan ini akan dirinci lebih lanjut pada tiga tahap yang berlangsung selama proses pengadaan tanah, yakni pelaksanaan pengadaan tanah, proses negosiasi, dan proses penerimaan kompensasi. Hal ini dapat dilihat pada tabulasi silang pada Tabel 20.

Tabel 20 Hubungan Tingkat Keterlibatan Perempuan dalam Tiga Tahap Pengadaan Tanah dengan Perubahan Peran Perempuan Setelah Pengadaan Tanah di Kalurahan Kebonrejo

\begin{tabular}{|c|c|c|c|c|c|c|c|c|}
\hline \multirow{3}{*}{$\begin{array}{l}\text { Tingkat Keterlibatan Perempuan } \\
\text { Selama Proses Pengadaan Tanah }\end{array}$} & \multicolumn{8}{|c|}{ Perubahan Peran Perempuan Setelah Pengadaan Tanah } \\
\hline & \multicolumn{2}{|c|}{ Rendah } & \multicolumn{2}{|c|}{ Sedang } & \multicolumn{2}{|c|}{ Tinggi } & \multicolumn{2}{|c|}{ Total } \\
\hline & $\mathbf{n}$ & $\%$ & $\mathbf{n}$ & $\%$ & $\mathbf{n}$ & $\%$ & $\mathbf{n}$ & $\%$ \\
\hline \multicolumn{9}{|l|}{ Tahap Pelaksanaan Pengadaan Tanah } \\
\hline Rendah & 7 & 23,3 & o & o & 1 & 3,3 & 8 & 26,7 \\
\hline Sedang & 11 & 36,7 & 4 & 13,3 & 2 & 6,7 & 17 & 56,7 \\
\hline Tinggi & 3 & 10 & 2 & 6,7 & o & o & 5 & 16,7 \\
\hline Total & 21 & 70 & 6 & 20 & 3 & 10 & 30 & 100 \\
\hline \multicolumn{9}{|l|}{ Tahap Proses Negosiasi } \\
\hline Rendah & 7 & 23,3 & o & o & o & o & 7 & 23,3 \\
\hline Sedang & 10 & 33,3 & 4 & 13,3 & 2 & 6,7 & 16 & 53,3 \\
\hline Tinggi & 4 & 13,3 & 2 & 6,7 & 1 & 3,3 & 7 & 23,3 \\
\hline Total & 21 & 70 & 6 & 20 & 3 & 10 & 30 & 100 \\
\hline \multicolumn{9}{|l|}{ Tahap Proses Penerimaan Kompensasi } \\
\hline Rendah & 16 & 53,3 & 5 & 16,7 & 1 & 3,3 & 22 & 73,3 \\
\hline Sedang & 4 & 13,3 & 1 & 3,3 & 1 & 3,3 & 6 & 20 \\
\hline Tinggi & 1 & 3,3 & o & o & 1 & 3,3 & 2 & 6,7 \\
\hline Total & 21 & 70 & 6 & 20 & 3 & 10 & 30 & 100 \\
\hline
\end{tabular}

Sumber: Data primer, 2020

Pada tahap pelaksanaan pengadaan tanah, Tabel 20 menunjukkan bahwa tingkat keterlibatan perempuan dalam kegiatan di tahap ini termasuk dalam kategori sedang dengan perubahan peran perempuan setelah pengadaan tanah termasuk dalam kategori rendah, di mana perempuan yang mengikuti kegiatan pelaksanaan tanah belum tentu memiliki peranan yang besar setelah pengadaan 
tanah. Untuk menguji hubungan di antara dua variabel tersebut, dilakukan uji Rank Spearman dengan hasil sebagai berikut.

Tabel 21 Hasil Uji Korelasi antara Tingkat Keterlibatan Perempuan dalam Pelaksanaan Pengadaan

Tanah dengan Perubahan Peran Perempuan Setelah Pengadaan Tanah di Kalurahan Kebonrejo

\begin{tabular}{lll}
\hline & & \multicolumn{1}{c}{$\begin{array}{c}\text { Perubahan Peran } \\
\text { Perempuan Setelah } \\
\text { Pengadaan Tanah }\end{array}$} \\
\hline $\begin{array}{l}\text { Tingkat Keterlibatan Perempuan dalam } \\
\text { Pelaksanaan Pengadaan Tanah }\end{array}$ & Koefisien Korelasi & 0,170 \\
& Sig (2-tailed) & 0,369 \\
& $\mathrm{~N}$ & 30 \\
\hline
\end{tabular}

Sumber: Data primer, 2020

Berdasarkan hasil uji korelasi ini dapat disimpulkan bahwa variabel tingkat keterlibatan perempuan dalam pelaksanaan pengadaan tanah tidak memiliki hubungan yang signifikan dengan variabel perubahan peran perempuan setelah pengadaan tanah. Nilai Correlation Coefficient bernilai positif sebesar 0,170 yang berarti bahwa arah hubungan dua variabel searah dan lemah.

"Tanahnya itu tanah warisan orang tua Bapak, tetapi yang dateng saya. Soalnya Bapak bolak-balik harus ke rumah sakit dan udah sakit-sakitan. Jadi saya yang ikut pertemuan Mbak. Uang ganti ruginya dibeliin rumah tapi ya atas nama Bapak, wong sebelumnya juga tanah warisan Bapak." (PYM, 69 tahun)

"Saya ikut pada saat rapat sosialisasi, walaupun itu tanah warisan dari mertua. Saya berpendapat dan diperbolehkan tapi tetap tidak mengubah apapun. Dari dulu sampai sekarang kalau mau beli apa-apa ya selalu didiskusiin bareng-bareng sama Bapak." (SPY, 52 tahun)

Berdasarkan penuturan dua informan di atas dapat diketahui bahwa faktor utama yang menentukan perubahan peran perempuan setelah pengadaan tanah bukan terletak pada tingkat keterlibatan perempuan dalam pelaksanaan pengadaan tanah, melainkan pada status kepemilikan tanah dan pada keputusan di dalam rumah tangga.

Selanjutnya, berdasarkan Tabel 20 juga terlihat bahwa tingkat keterlibatan perempuan dalam proses negosiasi termasuk kategori sedang dengan perubahan peran perempuan setelah pengadaan tanah termasuk dalam kategori rendah di mana perempuan yang mengikuti proses negosiasi juga belum tentu memiliki peran yang besar setelah pengadaan tanah. Untuk menguji hubungan di antara dua variabel ini, dilakukan uji Rank Spearman dengan hasil sebagai berikut.

Tabel 22 Hasil Uji Korelasi antara Tingkat Keterlibatan Perempuan dalam Proses Negosiasi dengan Perubahan Peran Perempuan Setelah Pengadaan Tanah di Kalurahan Kebonrejo

\begin{tabular}{lll}
\hline & & \multicolumn{1}{c}{$\begin{array}{c}\text { Perubahan Peran Perempuan Setelah } \\
\text { Pengadaan Tanah }\end{array}$} \\
\hline Tingkat Keterlibatan Perempuan & Koefisien Korelasi & 0,315 \\
dalam Proses Negosiasi & Sig (2-tailed) & 0,090 \\
& $\mathrm{~N}$ & 30 \\
\hline
\end{tabular}

Sumber: Data primer, 2020

Berdasarkan hasil uji korelasi ini dapat disimpulkan bahwa variabel tingkat keterlibatan perempuan dalam proses negosiasi tidak memiliki hubungan yang signifikan dengan variabel perubahan peran perempuan setelah pengadaan tanah. Nilai Correlation Coefficient bernilai positif sebesar 0,315 sehingga dapat disimpulkan bahwa arah hubungan dua variabel searah dan moderat. 
"Saya diskusi sama Bapak terkait sosialisasi, walaupun saya tidak ikut di forum tersebut. Sekarang kegiatan sosial saya tetap ikut pengajian di masjid. Namun ada beberapa yang berubah karena di tempat relokasi suasana baru, tetangga baru bahkan banyak pendatang." (TPN, 56 tahun)

"Saya dan anak saya yang ke balai desa sebagai perwakilan karena suami sudah sakitsakitan. Pas proses negosiasi saya ikut bahkan nanya kenapa dihargain segitu. Setelah itu, suami saya meninggal dan langsung saya bagi warisan ke anak-anak. Kalau bagian uang kompensasi saya sendiri saya beliin sawah lagi. Walaupun diburuh orang tapi kan hasilnya dibagi dua." (PNM, 6o tahun)

Berdasarkan penuturan dua informan tersebut bisa diketahui bahwa faktor utama yang menentukan perubahan peran perempuan setelah pengadaan tanah bukan terletak pada tingkat keterlibatan perempuan dalam proses negosiasi, melainkan pada keputusan dan peran perempuan di dalam rumah tangga.

Akhirnya, dari Tabel 20 juga terlihat bahwa tingkat keterlibatan perempuan dalam proses penerimaan kompensasi dengan perubahan peran perempuan setelah pengadaan tanah termasuk dalam kategori rendah. Perempuan yang mengikuti proses penerimaan kompensasi yang mencakup penandatanganan, penerimaan, dan penggunaan uang kompensasi belum tentu memiliki peranan yang besar setelah pengadaan tanah. Untuk menguji hubungan di antara dua variabel ini, dilakukan uji Rank Spearman dengan hasil sebagaimana dapat dilihat dalam Tabel 23.

Tabel 23 Hasil Uji Korelasi antara Tingkat Keterlibatan Perempuan dalam Proses Penerimaan Kompensasi dengan Perubahan Peran Perempuan Setelah Pengadaan Tanah di Kalurahan Kebonrejo

\begin{tabular}{lll}
\hline & & \multicolumn{1}{c}{$\begin{array}{c}\text { Perubahan Peran Perempuan Setelah } \\
\text { Pengadaan Tanah }\end{array}$} \\
\hline Tingkat Keterlibatan Perempuan dalam & Koefisien Korelasi & 0,161 \\
Proses Penerimaan Kompensasi & Sig (2-tailed) & 0,396 \\
& $\mathrm{~N}$ & 30 \\
\hline
\end{tabular}

Sumber: Data primer, 2020

Hasil uji korelasi ini menunjukkan bahwa nilai Sig. (2-tailed) sebesar 0,396 atau lebih besar dari o,05 sehingga dapat disimpulkan bahwa variabel tingkat keterlibatan perempuan dalam proses penerimaan kompensasi tidak memiliki hubungan yang signifikan dengan variabel perubahan peran perempuan setelah pengadaan tanah. Nilai Correlation Coefficient juga bernilai positif sebesar o,161 sehingga dapat disimpulkan bahwa arah hubungan dua variabel bersifat searah dan lemah.

"Yang nandatanganin Bapak karena dia sebagai pemilik sertipikat dan masih hidup. Tapi untuk yang nerima kan dalam bentuk cek, jadi pas ngambil ke bank saya ikut. Pengelolaan uang kompensasi juga bareng-bareng sama Bapak. Kalau untuk keputusan rumah tangga di tangan Bapak, nggak ada yang berubah dari dulu sampai sekarang. Bahkan kalau dulu saya ikut bertani ke sawah sekarang cuma jadi ibu rumah tangga." (SKI, 55 tahun)

"Nggak ada yang berubah sih Mbak, ya bedanya pindah rumah doang. Uang kompensasinya dibeliin tanah sama dibangun rumah baru. Paling Bapak cuma ngasih tau ke saya terkait prosesnya, tapi untuk nentuin beli apa pun dari dulu sampai sekarang yang nentuin Bapak. Kalau kerja dari dulu sampai sekarang ya sama berdagang bantu suami." (SYI, 40 tahun)

Berdasarkan penuturan dua informan di atas dapat diketahui bahwa faktor utama yang menentukan perubahan peran perempuan setelah pengadaan tanah bukan terletak pada tingkat keterlibatan perempuan dalam proses penerimaan kompensasi, melainkan pada keputusan dan peran perempuan di dalam rumah tangga. 
Dengan demikian, hasil uji statistik Rank Spearman menunjukkan bahwa tidak ada hubungan yang kuat antara tingkat keterlibatan perempuan sepanjang proses pengadaan tanah dengan perubahan perannya setelah pengadaan tanah. Faktor yang menentukan perubahan kondisi peran perempuan lebih banyak berupa pola relasi gender yang sudah ada di tingkat rumah tangga.

Selain itu, faktor lain yang lebih berpengaruh adalah dominannya kehendak dan kekuasaan pihak pemerintah selama keseluruhan proses pengadaan tanah itu sendiri. Apa yang sudah direncanakan oleh pemerintah tidak bisa diganggu gugat oleh siapa pun, bahkan sekalipun ada protes keras dari masyarakat seperti dilakukan oleh beberapa kelompok dari kalurahan lain.

Seluruh tahapan proses pengadaan tanah yang didominasi pengaruh kuat dari pemerintah ini juga tidak sensitif gender. Dalam arti, kesemua tahapan ini dilakukan tanpa memperhatikan aspirasi, kebutuhan dan kepentingan khusus kaum perempuan. Sebagai misal, Tim Appraisal yang melakukan penilaian ganti rugi tanah hanya berpedoman pada aturan hukum dan patokan nilai yang sudah ditentukan, tanpa mengindahkan pandangan dan usulan dari masyarakat. Kehendak pemerintah dalam pengadaan tanah yang tidak dapat ditentang dan dipengaruhi masyarakat ini menyebabkan keterlibatan perempuan yang relatif setara pada level rumah tangga menjadi tidak relevan baik sepanjang proses pelaksanaan pengadaan tanah itu sendiri maupun setelah pengadaan tanah.

\section{Kesimpulan}

Berdasarkan pembahasan terdahulu dapat disimpulkan bahwa sebelum pengadaan tanah, persentase jumlah perempuan yang menguasai tanah sebesar 20,59\% dengan persentase total luas penguasaan tanah sebesar 22,45\%. Dibandingkan dengan kondisi setelah pengadaan tanah, terjadi peningkatan dalam persentase jumlah perempuan yang menguasai tanah menjadi 37,14\%, namun persentase total luas penguasaan tanahnya berkurang menjadi $17,88 \%$. Dalam hal peran ekonomi perempuan, baik sebelum maupun setelah pengadaan tanah sama-sama didominasi oleh tingkat rendah, hanya saja persentasenya meningkat dari $56,7 \%$ menjadi $70 \%$. Ini menandakan bahwa setelah pengadaan tanah peran ekonomi perempuan semakin menurun. Sementara dalam hal peran sosial, baik sebelum maupun setelah pengadaan tanah sama-sama didominasi oleh tingkat sedang dengan kecenderungan yang juga semakin memburuk. Hal ini terlihat dari penurunan persentase tingkat sedang dari $80 \%$ menjadi $63,3 \%$.

Perubahan peran perempuan setelah pengadaan tanah ini ternyata tidak memiliki hubungan yang kuat dengan tingkat keterlibatan perempuan selama keseluruhan proses pengadaan tanah. Baik pada tahap pelaksanaan pengadaan tanah maupun proses negosiasi, tingkat keterlibatan perempuan didominasi oleh tingkat sedang, yaitu berturut-turut sebesar $56,7 \%$ dan $53,3 \%$. Sementara dalam proses penerimaan kompensasi, tingkat keterlibatan perempuan cukup rendah yaitu 20,93\% pada tahap penandatanganan dokumen, 21,62\% pada tahap penerimaan uang kompensasi, dan sedikit lebih baik mencapai $45,71 \%$ pada tahap pengelolaan uang kompensasi.

Meskipun secara keseluruhan tingkat partisipasi perempuan didominasi oleh tingkat sedang sebesar 46,7\%, namun uji statistik Rank Spearman menunjukkan bahwa tidak ada hubungan yang kuat antara tingkat keterlibatan perempuan sepanjang proses pengadaan tanah dengan perubahan peran perempuan setelah pengadaan tanah. Faktor yang menentukan perubahan kondisi perempuan ini ternyata lebih banyak terdapat pada pola relasi genderyang sudah ada di tingkat rumah tangga jauh sebelum pengadaan tanah berlangsung. Selanjutnya, faktor yang jauh lebih menentukan terletak pada asimetri kekuasaan yang lebih luas, yaitu relasi negara-rakyat yang sangat timpang di dalam kebijakan pengadaan tanah dan perlindungan hak rakyat atas penguasaan tanah dan harta lainnya yang terdampak oleh pengadaan tanah. 


\section{Daftar Pustaka}

Andriyani MF. (2011). Perubahan kondisi fisik dan ekonomi wilayah sekitar bandara selama pembangunan Bandara Internasional Lombok. [Skripsi]. Surakarta (ID): Universitas Sebelas Maret.

Az-Zahra YF. (2019). Analisis dampak sosial ekonomi pembangunan bandara New Yogyakarta Internasional Aiport terhadap kehidupan masyarakat di Kecamatan Temon, Kabupaten Kulonprogo, Daerah Istimewa Yogyakarta. [Skripsi]. Surakarta (ID): Universitas Muhammadiyah Surakarta.

Behrman J, Dick RM, Quisumbing A. (2012). The gender implications of large scale land deals. The Journal of Peasant Studies. [Internet]. [Diakses pada 22 Februari 2020]. 39 (1): 49-79. Tersedia pada : https://doi.org/10.108o/03066150.2011.652621

[BPS] Badan Pusat Statistik. (2013). Luas Lahan Menurut Penggunaan. Jakarta (ID): Badan Pusat Statistik Republik Indonesia.

Dewi NLGMP. Salim N. (2020). Berakhir di Temon: Perdebatan Panjang Pengadaan Tanah untuk [New] Yogyakarta International Airport. Yogyakarta (ID): STPN.

Himawan FU. (2018). Pembangunan internasional Yogyakarta dituduh ganggu lingkungan. BBC. com. [Internet]. [Diakses pada 11 Juli 2020]. Tersedia pada: https://www.bbc.com/indonesia/ majalah-44020249

Julia, WB. (2012). Gender experiences of dispossesion: oil palm expansion in a Dayak Hibun Community in West Kalimantan. The Journal of Peasant Studies. [Internet]. [Diakses pada 3 Maret 2020]. 39 (3-4): 995-1016. Tersedia pada: https://doi.org/10.108o/03066150.2012.676544

Kamaludin NK. (2019). Dampak proses pembangunan bandara di Kulonprogo. [Skripsi]. Yogyakarta (ID): Universitas Muhammadiyah Yogyakarta.

Levien M. (2017). Gender and land dispossesion: a comparative analysis. The Journal of Peasant Studies. [Internet]. [Diakses pada 12 Juli 2020]. 44 (12): 1-24. Tersedia pada: http://dx.doi.org/10.1080/o30 66150.2017.1367291

Limbong B. (2015). Pengadaan Tanah untuk Pembangunan. Jakarta (ID): Pustaka.

Majunder A. (2014). Impact of land acquisition on women: an anthropological case study on Gokulpur, Paschim Medinipur (India). IJMS. [Internet]. [Diakses pada 2 Agustus 2020]. 1(4): 26-34. Tersedia pada: http://europub.co.uk/articles/30578/view

Manembu AE. (2017). Peranan perempuan dalam pembangunan masyarakat desa. Jurnal Politico. [Internet]. [Diakses pada 28 Februari 2020]. 6(1): 114-123. Tersedia pada: https://ejournal.unsrat. ac.id/index.php/politico/article/view/16329/15832

Nhantumbo I, Salomao A. (2010). Biofuels, land access and rural livelihoods in Mozambique. International Institute for Environment and Development Working Paper. London(UK): IIED.

Probosiwi R. (2015). Perempuan dan peranannya dalam pembangunan kesejahteraan sosial. Jurnal Kajian Ilmu Administrasi Negara. [Internet]. [Diakses pada 22 Februari 2020]. 3(1): 41-56. Tersedia pada: https://doi.org/10.21831/jnp.v3i1.11957

Putsanra DV (2020). Nasib perempuan gusuran bandara YIA: dari petani jadi pengangguran. Tirto.id. [Internet]. [Diakses pada 8 Mei 2020]. Tersedia pada: https://tirto.id/nasib-perempuan-gusuranbandara-yia-dari-petani-jadi-pengangguran-fhCx

Shohibuddin M. (2018). Perspektif Agraria Kritis: Teori, Kebijakan, dan Kajian Empiris. Yogyakarta (ID): STPN Press.

Sopanudin A, Hendrastomo G. (2016). Konflik tanah pertanian dalam pembangunan bandara internasional di Kulonprogo. Jurnal Pendidikan Sosiologi. [Internet]. [Diakses pada 9 Februari 2020]. 6(1): 1-18. Tersedia pada:http://journal.student.uny.ac.id/ojs/index.php/societas/article/ view/8893 
Sumarja FX. (2014). Pengadaan tanah untuk pembangunan infrastruktur bersaranakan bangun guna serah. Bhumi. [Internet]. [Diakses pada 6 Mei 2020]. 40: 1-13. Tersedia pada: https://doi. org/10.31292/jb.voi40.187

Susanto H. (2020). Analisis dampak sosial ekonomi dalam pembangunan Bandara Yogyakarta International Airport (YIA) di Kabupaten Kulonprogo. Majalah Ilmiah Bijak. [Internet]. [Diakses pada 15 Juni 2020]. 17 (1): 1-9. Tersedia pada: https://doi.org/10.31334/bijak.v17i1.820.g460

Thukral EG. (1996). development, displacement and rehabilitation: locating gender. Economic and Politicak Weekly. [Internet]. [Diakses pada 22 Februari 2020]. 31(24): 1500-1503. Tersedia pada: https://www.jstor.org/stable/4404272?seq=1

[UU] Undang-Undang Nomor 2 Tahun 2012 Tentang Pengadaan Tanah bagi Pembangunan untuk Kepentingan Umum. [Diakses pada 6 Mei 2020]. Tersedia pada: https:// www.atrbpn.go.id / Desktop Modules / EasyDNNNews / Document Download. ashx?portalid=o\&moduleid $=1658 \&$ articleid $=866 \&$ documentid $=944$

Widyastuti AY. (2018). Pembebasan tanah Bandara Kulonprogo kembali dipersoalkan. Tempo.Co. [Internet]. [Diakses pada 11 Juli 2020]. Tersedia pada: https://bisnis.tempo.co/read/1126236/ pembebasan-tanah-bandara-kulon-progo-kembali-dipersoalkan

Yengoh GT, Armah FA, Steen K. (2015). Women's bigger burden: disparties in outcomes of large scale land acquisition in Sierra Leone Springer. [Internet]. [Diakses 2 Agustus 2020]. 32(4): 221-244. Tersedia pada: https://lup.lub.lu.se/search/publication/d 5c58oae-f49e-4f55-aac5-5d215b98f707

Yuliana T. (2017). Konflik pembebasan tanah untuk pembangunan infrastruktur jalan alterrnatif. [Skripsi]. Semarang (ID): Universitas Negeri Semarang. 